\title{
Remediation of Sites Contaminated by Organic Compounds
}

\author{
Lawrence C. Davis, Barbara Zeeb, Larry E. Erickson, \\ Aigerim Mamirova, and Valentina Pidlisnyuk
}

\begin{abstract}
The transformation and biodegradation of organic contaminants in soils with plants occur in plants as well as in soil. Microorganisms have the ability to biodegrade many compounds and microbial populations are larger when plants are present because of root exudates. In this chapter, petroleum compounds, explosives, solvents, pesticides, and persistent organic pollutants are included. Miscanthus, trees, and many other plants have important phytoremediation applications to organic contaminants. Phytoremediation studies with Miscanthus show that tolerance to organic contaminants is good and that Miscanthus is an effective plant for phytoremediation. Positive biodegradation results are reported with hemp, which is another plant with commercial value. Because of the importance to NATO, phytoremediation research progress with explosives is an important part of this chapter. There has been good research progress in phytoremediation applications with poplar trees where polychlorinated biphenyls have been investigated. Some recent phytoremediation advances with dioxins are included. Recent phytoremediation results with Miscanthus growing in pesticide-contaminated soil show that Miscanthus is able to grow in soils where mixtures of chlorinated pesticides are present.
\end{abstract}

\section{CONTENTS}

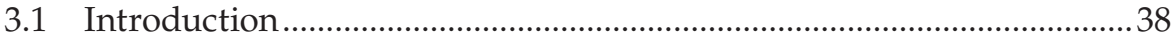

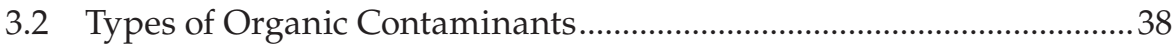

3.2.1 Remediation of Petroleum Contaminants...................................38

3.2.2 Remediation of Explosives......................................................... 41

3.2.3 Remediation of Chlorinated Hydrocarbons ..............................42

3.2.4 Remediation of Pesticides .................................................... 45

3.3 Landfills and Containment .......................................................... 47

3.4 Phytoremediation of Organic Contaminants with Miscanthus ...........48

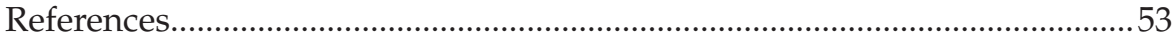




\subsection{Introduction}

There have been many studies of phytoremediation where organic contaminants are present and are the focus of the research or the cleanup. Phytoremediation with biomass production to obtain useful products is the emphasis in this book, but is far less common. If remediation goals at a site can be profitable because a useful product is harvested and sold, this has value for the project. With organic contaminants, it is possible to restore land to a state of productive use. In this chapter the emphasis will be on both soil remediation and how it can be accomplished by plants that have economic value. Miscanthus $\times$ giganteus (M. x giganteus) is the primary focus of this book, but because there is a dearth of information about the use of that plant in remediation of organics, most examples are drawn from other species.

\subsection{Types of Organic Contaminants}

There are many organic compounds present in soil and ground water as contaminants. Petroleum hydrocarbon (PHC) contaminated soil is one of the major areas of investigation and application as PHCs are among the most prevalent pollutants in the environment (e.g., Abdullah et al., 2020). For example, in Canada, approximately $60 \%$ of contaminated sites involve PHC contamination, often impairing the quality and uses of land and water (CCME, 2008). Hence, large land areas such as closed petroleum refineries, soils associated with restoration of coalmine lands, and spills at petroleum production areas need to be remediated. Explosives in soil are important in this book because of the emphasis on content that is of interest to NATO. Wood treatment sites with creosote, aircraft de-icing chemicals near airports, and many types of solvents at dry cleaners and vehicle repair shops are present in many countries. Persistent organic pollutants (POPs) such as the industrial chemicals, polychlorinated biphenyls (PCBs), and pesticides like DDT are present in soil as contaminants at many locations worldwide (Tarla et al., 2020). These organic contaminants adversely affect human and environmental health globally as they are subject to long-range transport via slow global distillation and persist in soils long after their initial deployment (Chlebek \& Hupert-Kocurek, 2019).

\subsubsection{Remediation of Petroleum Contaminants}

Petroleum spills and leaking tanks have resulted in many sites where organic compounds are present in soil. There is a significant literature on phytoremediation and bioremediation of soils with petroleum contaminants 
(Chan-Quijano et al., 2020; Fiorenza et al., 2000; McCutcheon \& Schnoor, 2003; Tang, 2019). Locations with petroleum and natural gas production operations, pipelines, refineries, storage sites, gasoline stations, vehicle maintenance shops, and parking lots are some of the places where hydrocarbons are routinely found in soils. Leaking underground storage tanks have been found at many locations including service stations, buildings where heating oil is used, and on farms where fuel for vehicles is stored.

Most PHCs have very low solubility in water and often the separation of a two-phase mixture of oil and water allows some valuable recovery of the oil phase when a "pump and treatment" system is used to recover product. Gasoline, kerosene, and diesel fractions are liquid at ambient temperature; however, some petroleum compounds are solids under ambient temperatures. When microorganisms feed on petroleum compounds, they may be found at oil phase surfaces. Polycyclic aromatic hydrocarbons (PAHs) are natural petrogenic materials although they can also be products of incomplete combustion of hydrocarbon fuels. Often, they are the most hazardous components of fuel spills because many PAHs are classified as carcinogenic (Cachada et al., 2016; Henner et al., 1997). Loss from soil to atmosphere is an important route of dispersal for petroleum fractions with reasonable vapor pressures, and fairly low water solubility. For instance, gasoline, kerosene, and jet fuel will dissipate from soils relatively quickly if the soil is porous. Plants which remove water from soils often facilitate diffusive loss of contaminants trapped beneath the water table by lowering the water table.

Petroleum compounds provide carbon and energy, but nitrogen $(\mathrm{N})$ and phosphorus $(\mathrm{P})$ are also needed to support growth of both the plants and microorganisms. Because $\mathrm{N}$ and $\mathrm{P}$ are needed, fertilizer is often added as part of the phytoremediation plan. Organic fertilizers such as manure add to microbial diversity, which is often beneficial (Chan-Quijano et al., 2020). Many different bacteria participate in the biodegradation of PHCs, and some authors have generated lists of different species that have been isolated (e.g., Chan-Quijano et al., 2020). Research on the biodegradation of hydrocarbons was ongoing when phytoremediation research to address PHCcontaminated soil began in the 1990s.

Several of the early field studies in the 1990s were carried out by Banks and coworkers (Fiorenza et al., 2000). The results from several field studies are included in McCutcheon \& Schnoor (2003). Grasses have been among the more beneficial plants in the research on biodegradation of petroleum compounds (Chapter 11 by Hutchinson, Banks and Schwab in McCutcheon \& Schnoor (2003)). Although many forage grasses have only very limited use in industrial biomass production, the early research demonstrated beneficial effects of plants in field-scale PHC degradation. Plant roots provide an active environment, which contains compounds and organisms that are beneficial for microbial degradation processes. Often, they enhance soil aeration by 
removing pore water. Many degradative reactions are oxygen-dependent, although some are anaerobic.

One good example of phytoremediation using trees for removing fuel contaminants from a shallow aquifer was reported by Nichols et al. (2014). In their study, $579,000 \mathrm{~L}$ of diesel, jet fuel, and gasoline (all moderately volatile) were present at the start of the project in an area of two hectares. Poplar, willow, and pine trees were planted at the site in 2006 with most of the 3250 trees being poplars. When poplar and willow trees died, they were replaced by cuttings from the healthy trees at the site. Soil-gas sampling was used to follow the progress of the remediation and determined a 95\% loss of total PHCs (TPH), and a $99 \%$ loss of mass of benzene (very volatile). As the trees grew, their ability to pump water increased and this was beneficial. In this example, the TPHs were all liquids at ambient conditions. Methyl-tert-butyl ether (MTBE), a highly water-soluble fuel additive, was taken up by the trees and released to the atmosphere. As the rate of release to the atmosphere was limited by the rate of evapotranspiration of the water that the MTBE was dissolved in, the concentration of MTBE in the atmosphere was very small (Narayanan et al., 1999), and in addition, MTBE has a very short atmospheric half-life on the order of 3 days (Squillace et al., 1997). There is no doubt that other constituents passed through the trees at lower levels proportional to their water vs lipid solubility. Toxicity to plants would limit this uptake for levels of benzene, toluene, ethylbenzene, and xylenes. Less polar lipids, found in crude oil and environmentally aged petroleum fractions, are generally much less toxic.

Combining the use of vascular plants and microbes (bacteria and/or fungi) is proving to be a promising approach for degrading a variety of organic contaminants including PHCs. Studies carried out recently have largely focused on the potential of endophyte and rhizosphere plant growth promoting bacteria to increase the efficiency of phytodegradation (e.g., Becerra-Castro et al., 2013; Chlebek \& Hupert-Kocurek, 2019). These bacteria, possessing catabolic genes, mineralize organic contaminants within the plant or rhizosphere, reducing their phytotoxicity, while promoting the growth and development of plant root and shoot biomass (e.g., Afzal et al., 2014; Arslan et al., 2017; Glick, 2010; Santoyo et al., 2016).

Cannabis sativa is an annual dioecious herb capable of growing to heights of $5 \mathrm{~m}$ and having long tap roots. This plant has been grown since ancient times for use in a wide range of applications. Fibers from hemp are extensively used in products that include fabrics and textiles, ropes, yarn, carpeting, construction and insulation materials, etc. (Johnson, 2014). The short and woody fibers in the hemp's stalk interior are known as "hurds" and are used in the manufacture of animal bedding, paper, and composites. Hemp seed is used in various foods and beverages and oil from hemp seed is widely used in industrial oils, cosmetics, and pharmaceuticals. In addition, cannabinoids, a group of compounds found in Cannabis (with the most notable being the phytocannabinoid tetrahydrocannabinol (THC)), are used medicinally, spiritually, and recreationally (e.g., Bilalis et al., 2019). The term "hemp" is used 
to denote cannabis that contains $0.3 \%$ or less THC content by dry weight. In recent years, C. sativa (hemp) has been studied as a bioenergy crop as it grows well on marginal lands and has the capacity to produce high volumes of biomass (e.g., Kumar et al., 2017). Asquer et al. (2019) reported biogas production using hemp straw was comparable to most other energy crops. This annual crop can be grown in climates where winters are too cold, making successful maintenance of perennial $M$. x giganteus unreliable.

C. sativa (hemp) was studied in the remediation of two PAHs, benzo[ $\alpha]$ pyrene and chrysene (Campbell et al., 2002). The authors carried out experiments over 45 days in soil spiked with benzo[ $\alpha]$ pyrene and chrysene at 25, 50, and $75 \mu \mathrm{g} \mathrm{g}^{-1}$ and found reductions in contaminants in all cases. They additionally found that the mass and growth of Cannabis plants to increase at all three concentrations leading them to suggest that metabolites of the two PAHs studied may have stimulated the growth of hemp.

Research to improve PHC phytoremediation processes is continuing, and there has been significant progress in the last 6 years. In 2019, Tang reviewed studies on the biodegradation of TPHs (Tang, 2019). Ren et al. (2017) discuss in detail some of the complexity in remediating PHC because the larger aromatics are tightly sorbed to organic matter, and minerals of soil giving them very low accessibility to organisms. The sorption/desorption processes are challenging to predict for the vast number of constituents in PHC mixtures such as crude oil, and residuals from refining. Laboratory experimentation may not align well with effects observed in the field with "aged" materials because of the very slow rates of sorption/desorption observed in real soil structures, particularly in micropores of mineral or biochar fractions (Ren et al., 2017).

\subsubsection{Remediation of Explosives}

Large areas of land are contaminated with explosives or their residues. Landmines, unexploded ordnance (UXO), and explosive compounds in soil are important issues in many countries. Globally more than 80 countries have land contaminated by explosives (Robledo et al., 2009), including more than 100 million antipersonnel mines (Hemapala, 2017). In Europe, there are UXOs from World War 2 that still need to be removed. For example, Ukraine has $~ 7000 \mathrm{~km}^{2}$ of land with UXOs, and this resulted in 2078 casualties from 2014 to 2017 (Dathan, 2020). Due to military conflicts in Asia and the Middle East, more than 150 million ha have explosives present as UXOs and/or as contaminants in soil (Via, 2020). In the USA, there are more than 2000 sites with soil contamination due to explosives (Via, 2020). Contaminated soil locations include sites for the manufacture of explosives, assembly plants where explosives are, or were, packed into shells, and sites where explosives have been stored.

There has been good progress in developing robotic methods to identify and remove landmines, one of the principal forms of UXO (Hemapala, 2017; Robledo et al., 2009). Kalderis et al. (2011) provided a comprehensive review of research 
on the biodegradation of TNT (2,4,6-trinitrotoluene), RDX (Royal Demolition Explosive; cyclotrimethylene-trinitramine; 1,3,5-trinitroperhydro-1,3,5-triazine), and HMX (high-melting explosive; octogen; cyclotetramethylene-tetranitramene; 1,3,5,7-tetranitro-1,3,5,7-tetrazocane). Water solubility is largest for TNT $\left(130 \mathrm{mg} \mathrm{L}^{-1}\right)$, followed by RDX $\left(42 \mathrm{mg} \mathrm{L}^{-1}\right)$, and HMX $\left(5 \mathrm{mg} \mathrm{L}^{-1}\right)$ facilitating their transfer to organisms. Biodegradation pathways are presented in the Kalderis' et al. (2011) review. The greatest success to date with bioremediation and phytoremediation has been with TNT, the simplest and most soluble of the common explosives. Lists of bacteria and fungi that biodegrade TNT, RDX, and HMX are provided in the Kalderis et al.'s (2011) review along with data on toxicity of these explosive compounds to microorganisms and invertebrates.

Phytoremediation field studies of TNT have been reported, and a good summary of the few reported, is provided by Via (2020), along with degradation pathways of TNT within plants, and a list of plants with results. A field-scale wetland treatment system for TNT and RDX in water was designed and implemented at the Iowa Army Ammunition Plant (McCutcheon \& Schnoor, 2003).

The concept of phytoremediation with biomass production on sites with explosive contaminants needs further development. One tropical biomass crop, vetiver grass (Chrysopogon zizanoides), a relative of sorghum, has been tested for its capacity to take up and degrade TNT (Das, 2014). When urea was added to the soil system, uptake increased as much as $90 \%$ of the input $100 \mathrm{mg} \mathrm{kg}^{-1}$ amount of TNT in 22 days. Miscanthus may be a good plant for field-scale phytoremediation of soils contaminated with explosive compounds; however, further research is needed on the fate of TNT, RDX, and HMX in soils where Miscanthus is grown. In many cases, the actual degradation is microbially driven, and hence many different plant species may facilitate the process (Esteve-Núñez et al., 2001). On the other hand, TNT metabolism and detoxification within plants may differ between plant species. The process has been well characterized in the dicot Arabidopsis (Gandia-Herrero et al., 2008), but thus far not in grasses.

\subsubsection{Remediation of Chlorinated Hydrocarbons}

Many chlorinated organic compounds have found their way into soil and ground water. The liquid forms are especially challenging to deal with because they are often denser than water and move to the bottom of an aquifer, gradually contaminating that water by slow diffusive dissolution. Chlorinated solvents such as trichloroethylene have been used for a number of beneficial applications in machine shops and dry-cleaning operations, and they are found in soil and groundwater at many locations. Volatile solvents dissolved in water can be taken up into plant roots. Plant evapotranspiration releases water into the atmosphere and the chlorinated solvents in the water are released into the atmosphere. Because of the low vapor pressure of water at ambient temperatures, only about $18 \mathrm{mg} \mathrm{L}^{-1}$ of water $(1 \mathrm{mM})$ can be evaporated into the air phase. In consequence, huge volumes of air are needed for evapotranspiration, and thus the concentrations of the volatile chlorinated 
solvents in the air are very low. The dilution factor of this process is about 55,000 , varying with temperature and relative humidity of the "incoming" air (Narayanan et al., 1995, 1999). In the atmosphere, trichloroethylene has a short half-life as solar radiation generates hydroxyl radicals.

Keeping soluble chlorinated organic compounds out of drinking water sources is challenging. Once they have found their way into an aquifer, in situ treatment in the aquifer may be a better treatment alternative than pumping the water out (Santharam et al., 2011). The effectiveness of phytoremediation is limited by the ability of roots to reach the contamination. Sometimes efforts are made to install trees below the soil surface, in an excavated pit or well, in order to reach the contaminated zone (Negri et al. in McCutcheon \& Schnoor, 2003).

There are many examples of phytoremediation field studies where microbial transformations and evapotranspiration of chlorinated aliphatic compounds are observed (McCutcheon \& Schnoor, 2003). The vegetation effectiveness is better for contaminants that are near the soil surface compared to aquifers that are located deeper below the ground surface. Vegetation has been used to pump contaminated water into the atmosphere as a way to manage contaminants that are present at a site (Doucette et al. in McCutcheon \& Schnoor, 2003). An alternative is to pump contaminated water to the surface and use it to irrigate trees or other vegetation (Jordahl et al. in McCutcheon \& Schnoor, 2003). Deep-rooted, water-seeking trees have been used effectively and economically for remediation of chlorinated compounds (Shang et al. in McCutcheon \& Schnoor, 2003). They have value when harvested.

PCBs are classic examples of POPs. They are primarily an intentional industrial product, used for 50 years or more as an insulating oil (liquid) in capacitors and electrical transformers (USEPA, n.d.). Their extreme hydrophobicity results in strong sorption to organic matter in soils. As discussed by Ren et al. (2017), the nature of sorption may vary with the nature of the soil matrix, depending on the specific types of transformed organic matter present, and types of clay and other minerals in the soil. Thus, different PCB congeners may sorb/desorb differently on different soils. The same caveat applies to dioxins and pesticides (see below).

The ability of microbe and plant species to access these POPs varies greatly, depending on whether the plant or microbe produces surfactants, or specific lipid binding proteins in the rhizosphere (Terzaghi et al., 2021). Those authors compared seven species and some combinations of species, including pumpkin with fescue, and the effect of compost or redox cycling with fescue. Other species were treated with other methods including redox cycling, pairwise growth, or ammonium thiosulfate addition. Fescue and a combination with pumpkin gave the best rates of degradation of the complex mixture of PCBs, of which they analyzed 79 congeners. This included the most highly chlorinated classes. They noted that levels of organic $C$, as compost, altered rates. It was proposed that it serves as a source of dissolved organic carbon which facilitates microbial degradation of PCBs. 
Biochar, the charcoal obtained by incomplete combustion of plant material, may alter the relative sorption of POPs. For example, in a greenhouse experiment, the addition of $2.8 \%$ (by weight) biochar to soil contaminated with 136 and $3.1 \mu \mathrm{g} \mathrm{g}^{-1}$ of PCBs, reduced PCB root concentration in the known phytoextractor Cucurbita pepo ssp. pepo by $77 \%$ and $58 \%$, respectively, in addition to increasing aboveground plant biomass (Denyes et al., 2012). Further, in the first in situ experiment conducted at a Canadian PCB-contaminated Brownfield site, two types of biochar were statistically equal at reducing PCB uptake into plants as granular activated carbon (AC), reducing $\mathrm{PCB}$ concentrations in C. pepo root tissue by up to $74 \%$ (Denyes et al., 2013). Biochar-equivalent may be a natural material in black soils, where the black color is due to ancient and modern products of fires. Nartey \& Zhao (2014) thoroughly review various processes for the production of biochars and Denyes et al. (2014) discuss the importance of their physical, chemical, and biological characterization.

Ficko et al. (2011) conducted a field study in which three promising phytoextracting perennial weed species (Chrysanthemum leucanthemum, Rumex crispus, and Solidago canadensis) were planted in monoculture plots at two PCB-contaminated sites in southern Ontario and followed over 2 years to investigate the effects of plant age, contaminant characteristics, and species-specific properties on PCB uptake and accumulation patterns in plant tissues. Results indicated that shoot contaminant concentrations and total biomass were dependent on plant age and life cycle (vegetative and reproductive stages), which affected the total amount of PCBs phyto-extracted on a per-plant basis. Even at suboptimal planting densities of 3-5 plants $\mathrm{m}^{-2}$, all three weed species extracted a greater quantity of PCBs per unit area (4800$10,000 \mu \mathrm{g} \mathrm{m}^{-2}$ ) than the known PCB-accumulator Cucurbita pepo. Calculated PCB extractions based on theoretical optimal planting densities were significantly higher at both sites and illustrated the potential of these weeds for site remediation.

An excellent example of plant-assisted remediation using trees may be found in Ancona et al. (2017). They used poplar trees, with drip irrigation, to remediate a site near transformers at a power station in southern Italy. At this site, which was also used as a dump for assorted wastes, the long-term spillage of PCB oils followed by recent efforts to clean up the site had dispersed into the soil to depths up to $40 \mathrm{~cm}$. Within 1 year of planting trees, in rows spaced $2 \mathrm{~m}$ apart with trees at $0.5 \mathrm{~m}$ within the rows, levels of many congeners decreased from more than fivefold above regulatory limits to levels below those limits. The effect decreased as distance from the trees increased. Some lesser chlorinated congeners were taken up into the trees in limited amounts, while other more hydrophobic (more chlorinated) ones sorbed tightly to the roots. Overall, soil levels decreased $>90 \%$, and levels within the trees did not exceed those of the rhizosphere, despite large uptake of water over the course of a year. This result is not unexpected. Ancona et al. (2017) cite more than 50 articles describing microbial and plant-assisted degradation of PCBs, though mostly in pot studies. Chekol et al. (2004) documented the rhizosphere effect for PCBs with three legumes and four grasses, 
while Liu \& Schnoor (2008) quantitatively documented the preferential uptake of lesser chlorinated PCBs into hydroponic poplars.

Dioxins (polychlorodibenzo- $p$-dioxins) are chlorinated aromatic compounds similar to PCBs but having two oxygen bridges between two benzene rings. Polychlorinated benzofurans have one oxygen bridge and one direct benzene-benzene bond. They arise as by-products of chlorination of phenols and during combustion of organic matter in the presence of $\mathrm{O}$ and $\mathrm{Cl}$ (Campanella et al., 2002). All of these are toxic to greater or lesser extent, but very persistent in environment, and so nonpolar that they accumulate in lipids of living organisms, and hence through the food chain. Fungi and root-associated organisms may facilitate their degradation. Bacteria of several genera are known to degrade specific congeners with varying efficiency. Many are aerobes, but some dechlorinations occur with anaerobes (Field \& Sierra-Alvarez, 2008). Plants have been used to enhance the rates of degradation by providing nutrients to microbes, aerating the root zone, inducing microbial metabolism enzymes, and to do some metabolic reactions within the plant (Campanella et al., 2002). Over the past two decades there have been advances in this area, but challenges remain (Mench et al., 2010). There are many more recent papers discussing degradation of these compounds by microbes (Saibu et al., 2020), but little new work with plant pathways.

\subsubsection{Remediation of Pesticides}

At many locations in the world, soils are contaminated with pesticides because of poor management, spills, and the need to clean out sprayers. A recent review describes applications of phytoremediation to restore lands that are contaminated with pesticides (Tarla et al., 2020). The toxicity of pesticides to vegetation is one of the challenges in selecting plants for use at a contaminated site. There has been progress in the identification and use of microorganisms and plants that have good capability to degrade some pesticides. Soil amendments such as manure or biochar can be added to contaminated sites to dilute pesticides, sorb them out of soil solution, and provide additional microorganisms to aid in the establishment of vegetation. Use of vegetation that naturally grows well in the region is recommended.

Khalid et al. (2020) review many applications of biochar specific to pesticides. Deliberate augmentation with biochar to enhance bioremediation is becoming a common practice; however, sorption to biochar also reduces availability of pesticides and herbicides to plants, and can thus delay their remediation (Khalid et al., 2020). For example, in an in situ study at Point Pelee National Park in Canada (PPNP), biochar significantly reduced DDT (p, $\mathrm{p}^{\prime}$-dichlorodiphenyl-trichloroethane) accumulation in earthworms (49\%) but did not significantly reduce plant uptake of DDT (Denyes et al., 2016). Other amendments, particularly other carbon-rich materials including humic substances, charcoal, bio-coal and AC, sorb the contaminants in soils (Beesley et al., 2011) and may also reduce the bioavailability for plants (Khalid et al., 2020). It is important 
to note that as shown by Nartey \& Zhao (2014) different kinds of biochar prepared in different ways from different starting materials may have different effects.

Among pesticides, there is a large class of obsolete pesticides (insecticides) containing significant amounts of chlorination, resulting in persistence. Examplesincludealdrin/dieldrin/endrin,lindane ( $\alpha$-hexachlorocyclohexane), chlordane, chlordecone (Kepone), DDT, heptachlor, toxaphene, and others. Many of these are banned in many countries, but residues and waste/ abandoned sites are still present (Agbeve et al., 2013; Tarla et al., 2020). Weathered DDT is still found in many locations, and portions of Africa continue to use it for control of malaria-bearing mosquitos (Tarla et al., 2020). Many other pesticides are present in agricultural/horticultural soils and in plants harvested from such soils. For instance, Agbeve et al. (2013) found $\beta-\mathrm{HCH}, \delta-\mathrm{HCH}, \gamma-\mathrm{HCH}$, heptachlor, aldrin, $\gamma$-chlordane, $\alpha$-endosulfan, p.p'-DDE (2,2'-p,p'dichlorodiphenyl-1,1-dichloroethene), dieldrin, endrin, $\beta$-endosulfan, p.p'-DDD (2,2'-p,p'dichlorodiphenyl-1,1-dichloroethane, p.p'DDT, and methoxychlor in roots of Cryptolepis sanguinolenta, a traditional antimalarial herb of Ghana, in both dry and rainy season's growth. Roots were thoroughly washed before analysis, which may have reduced the pesticide load, though perhaps not completely, as sorption is quite strong on root surfaces. The detected levels were below regulatory limits except for some samples with high aldrin/dieldrin. It is not known whether the various pesticides were long-term residues, or from banned products still being used. Tarla et al. (2020) discuss some of the problems with waste pesticide disposal.

There is potential for phytoremediation of DDT because it is taken up by some vascular plants (Lunney et al., 2004) particularly some species of the Cucurbitaceae family. Zucchini, a popular edible vegetable, accumulates large amounts from contaminated soil. It also accumulates aldrin, dieldrin, and endrin, such that it may be used to remove these residues from agricultural lands long contaminated with high levels, above current regulatory limits (Otani et al., 2007). However, very few species take up these compounds (only 2 of 15 families tested by Otani et al. (2007)), limiting ability to clean up many sites.

Paul et al. (2015) conducted a field investigation at three DDT-contaminated areas in PPNP in Canada. Cucurbita pepo (pumpkin) and three native grass species, Schizachyrium scoparium, Panicum virgatum, and Sporobolus cryptandrus, were grown at three different sites in PPNP having low $\left(291 \mathrm{ng} \mathrm{g}^{-1}\right)$, moderate (5083ng $\left.\mathrm{g}^{-1}\right)$, and high $\left(10,192 \mathrm{ng} \mathrm{g}^{-1}\right)$ soil DDT contamination levels. A threshold soil DDT concentration was identified at $\sim 5000 \mathrm{ng} \mathrm{g}^{-1}$ where the DDT uptake into C. pepo was maximized, resulting in plant shoot and root DDT concentrations of 16,600 and $45,000 \mathrm{ng} \mathrm{g}^{-1}$, respectively. Two of the native grass species (P. virgatum and S. scoparium) were identified as potential phytoextractors, with higher shoot extraction capabilities than that of the known phytoextractor C. pepo when optimal planting density was taken into account. Hexachlorocyclohexane, a common persistent contaminant (Agbeve et al., 2013; Tarla et al., 2020), has been remediated using plants also (Becerra-Castro et al., 2013). 
White and Kottler (2002) used citric acid to augment the remediation of weathered DDT/DDE (DDT metabolite) with four species of plants including clover, hairy vetch, mustard, and ryegrass. Uptake of DDE was significantly increased while the region around the roots was depleted in concentration. Other surfactants and organic acids have been used to enhance the release of POPs. This is commonly characterized as chemically augmented phytoremediation. In order to improve the phytoremediation potential of plants and microbes, one may try using surface-active compounds including synthetic or biosurfactants (Agnello et al., 2014; An et al., 2011; Ramamurthy \& Memarian, 2012); several different organic acids (Agnello et al., 2014; Gonzalez et al., 2010); and nanoparticles (Pillai \& Kottekottil, 2016; Rani et al., 2017).

Herbicides, fungicides, and insecticides produced and used in recent years tend to have less residual action and decreased environmental stability than highly chlorinated POPs. Nevertheless, their remediation/detoxification is still necessary to avoid toxic effects on nontarget organisms during accidental exposure, and from field run-off during sudden rains, as they are typically applied at concentrations that are $>100 \times$ toxic levels (e.g., Fairchild et al., 1998; Plhalova et al., 2012).

Loffredo et al. (2020) found Cannabis sativa L. seedlings to be very effective in removing the systemic fungicide metalaxyl-M from water. Residual compounds accumulated in the hemp tissues over 7 days were much lower than the amounts removed from the medium, suggesting efficient metabolization. When hemp was allowed to germinate and grow in columns filled with soil contaminated with metalaxyl-M and the herbicide, metribuzin, it showed a noticeable remediation capacity. The authors used this study to suggest that hemp is a promising candidate for phytoremediation of wastewater and soil from pesticides.

\subsection{Landfills and Containment}

Containment of contaminants is an issue at landfills where waste is deposited and managed. In order to control contaminant movement within landfills, trees are often planted on the down gradient side to remove contaminated leachate from the site. This concept has also been used at the edges of fields to capture agricultural chemicals with a riparian strip to prevent them from entering a creek or river. There are significant savings when vegetation is used for pump-and-treat applications (Negri et al. in McCutcheon \& Schnoor, 2003). The organic contaminants may be biodegraded or transpired and destroyed in the atmosphere. Trees that have the ability to reach the water table and have value when harvested are generally recommended for these applications. Trees have been used to some extent directly on landfill covers, but native plants, including shrubs and forbs, are recommended (USEPA, 2015). Deep-rooted grasses may also be effective. Grasses have been 
widely used for landfill covers to reduce water infiltration, but less so as a means to control leachate, once it is formed. Gąbka \& Wolski (2011) described a successful study of active management of leachate by watering various turf grasses with collected landfill leachate at a closed landfill in Poland. In warm subtropical to tropical climates, vetiver grass has been used since 1994 and shown to be highly effective for managing a wide range of leachates either actively by irrigation, or passively by planting directly into the leachate seepage path (Vetiver Network International, 2017). Miscanthus has suitable characteristics for temperate climates including deep rooting where potential crop evapotranspiration exceeds normal precipitation (see Chapter 5 for information on water usage by Miscanthus).

\subsection{Phytoremediation of Organic Contaminants with Miscanthus}

Miscanthus is a $\mathrm{C}_{4}$ grass related to sugarcane and sorghum, with a rich microbiome. Thus, it is anticipated that it can facilitate rhizoremediation of many organic compounds. Field data on its capacity to do so are not abundant because until recently cultivation of Miscanthus was of most interest as a source of bioenergy, not remediation of contaminated sites. There are a limited number of greenhouse pot studies with selected compounds. These are discussed in reviews by Nsanganwimana et al. (2014) and Pidlisnyuk et al. (2014). By that date only the work of Técher et al. (2012a) reported a field study of significant organic [PAH] contamination. That same group showed that exudates of Miscanthus roots stimulated microbial degradation of some PAHs in microcosm studies (Técher et al., 2012b), while an earlier study showed enhancement of degradation of diesel fuel also (Técher et al., 2011).

One recent study (Wechtler et al., 2020) examined dissipation of PAHs from a technosol (mixture of dredged sediments and contaminated soil). Plants used were M. x giganteus, white clover (T. repens), and a co-culture of the two. After a growing season of 263 days, there was a significant decrease of 16 priority PAHs, with $\sim 30 \%$ decrease in the monocultures and co-culture compared to an unplanted technosol. This lowered the integrated average cancer risk from about 4.3 to 3.4. The co-culture also lowered the predicted ecotoxicity more than each monoculture, showing a greater decrease of anthracene and pyrene.

Miscanthus is known to have resistance to herbicides similar to that of maize (Anderson, 2011), but mechanisms are undefined, whether by metabolic tolerance, deactivation of the herbicide or exclusion from the plant. Anderson (2011) tested more than 20 herbicides, at several rates of application for control of broad-leaf weeds or other grasses (pre-emergence). Many herbicides were tested in greenhouse studies and some at small scale in a field. 
Recalcitrance of PAHs and PCBs varies widely so that success with a few congeners or homologs is no guarantee of success with all forms. The earliest remediation study with Miscanthus that we can identify was by Wilke and Metz (1993). They analyzed a suite of six PCB congeners and six PAHs from a long-term contaminated site in Germany, which also had high levels of toxic metals including $\mathrm{Cd}$ and $\mathrm{Zn}$ relative to regulatory standards. The contamination source was sewage sludge irrigation and the soil total organic carbon was $6.7 \%$. Growth of Miscanthus sinensis (M. sinensis) or Polygonum sachalinense was less effective in the undiluted soil containing $72 \mathrm{mg} \mathrm{kg}^{-1}$ of $\mathrm{Cd}$ and $1800 \mathrm{mg} \mathrm{kg}^{-1}$ of $\mathrm{Zn},>1600 \mu \mathrm{g} \mathrm{kg}-1$ of PCBs and $3062 \mu \mathrm{g} \mathrm{kg}-1$ of PAHs than in a soil diluted with brown podzol. That soil had only $0.77 \%$ of TOC and a $\mathrm{pH}$ 4.1. It is not known which element or compound was the main contributor to growth inhibition. Depending on bioavailability, Zn at $1800 \mathrm{mg} \mathrm{kg}^{-1}$ at the $\mathrm{pH}<5(\mathrm{pH} 4.8$ in undiluted soil) could be strongly inhibitory. Over a range of dilutions giving $1 \times, 5 \times, 10 \times, 20 \times$ of the regulatory limit of $1.5 \mathrm{mg} \mathrm{kg}^{-1}$ for Cd, both PCBs and PAHs were accumulated only in roots, to a maximum of $975 \mu \mathrm{g} \mathrm{kg}-1$ of PCBs and $2083 \mu \mathrm{g} \mathrm{kg}-1$ of PAHs at approximately 1:1 dilution of the contaminated soil (to $20 \times 1.5 \mathrm{mg} \mathrm{kg}^{-1}$ of Cd). Degradation products were not measured. Neither PCB nor PAH congeners were detected in stems and leaves in this pot study. No more recent studies with PCBs have been reported.

Little is known of the tolerance or degradation capacity of Miscanthus for POPs including chlorinated pesticides. One study was completed with the insecticide chlordecone (trade name Kepone) by Liber et al. (2018). This persistent material with a half-life of $\sim 30$ years may be present in soils at levels of $>1 \mathrm{mg} \mathrm{kg}^{-1}$. Using 14-C labeled material in a greenhouse study with dense planting of 49 plants in $0.81 \mathrm{~m}^{2}$, accumulation above soil level (expressed as $\mathrm{mg} \mathrm{kg}^{-1}$ ) was observed only in roots of both $M . \times$ giganteus $\left(5 \mathrm{mg} \mathrm{kg}^{-1}\right.$ in roots, $0.17 \mathrm{mg} \mathrm{kg}^{-1}$ in rhizomes, $0.15 \mathrm{mg} \mathrm{kg}^{-1}$ in shoots) and $M$. sinensis ( $15 \mathrm{mg} \mathrm{kg}^{-1}$ in roots, $0.5 \mathrm{mg} \mathrm{kg}^{-1}$ in rhizome, $0.3 \mathrm{mg} \mathrm{kg}^{-1}$ in shoots) during the second growing period of 2 and then 6 months. In a second experiment with $M$. sinensis over two growth periods of 10 months each, accumulation into aboveground tissues from $8 \mathrm{mg} \mathrm{kg}^{-1}$ in soil was less in the second period, to only about $2 \mathrm{mg} \mathrm{kg}^{-1}$, presumably because of increased organic matter in the root zone. Calculated harvestable plant contamination under hypothetical field conditions ( $1 \mathrm{mg} \mathrm{kg}^{-1}$ soil) indicated about $1 \mathrm{~g} \mathrm{ha}^{-1}$ year $^{-1}$ would be removed by harvesting Miscanthus. With a contaminant load of perhaps $2 \mathrm{~kg} \mathrm{ha}^{-1}(\sim 1 \mathrm{mg}$ $\mathrm{kg}^{-1}, \sim 20 \mathrm{~cm}$ depth). This is a trivial amount for recovery, though important for appropriate use of the harvested crop.

A study by Nurzhanova et al. (2017) presented the application of $M$. sinensis to phytoremediation of soil heavily polluted by DDT and its metabolites. The aged contaminated soil was sampled around a destroyed storehouse for chlorinated pesticides in Kazakhstan, and chemical analysis showed large pesticide concentrations in the soil. For example, DDT concentrations in the soil exceeded the maximum permissible concentration (MPC) limit value by 62 
times. The results showed that $M . \times$ giganteus could not develop in soil with a concentration of DDT higher than $45 \times$ MPC limit of DDT and its metabolites, while $M$. sinensis was able to develop in pesticide contaminated soil till $62 \times$ MPC. The observation showed (Table 3.1) that M. x giganteus mainly accumulated the chlorinated pesticides in roots despite high pesticide concentration in the soil. With increasing concentration of DDT and its metabolites in the soil, the total uptake of 4,4'-DDE increased, uptake of 2,4'-DDD remained the same, and uptake of DDT decreased. In the case of $M$. sinensis, 4,4'-DDE and $4,4^{\prime}$-DDT were mainly accumulated in roots while $2,4^{\prime}$-DDD appeared more in aboveground biomass (Nurzhanova et al., 2017).

The phytoremediation potential of $M$. sinensis and the influence of two amendments, Tween 20 and AC added to the process, was studied with aged polluted soil from Kazakhstan (Mamirova et al., 2020). The soil contained heavy metals and 24 chlorinated pesticides (DDT and metabolites, $\mathrm{HCH}$ and isomers, endrin, keltan, aldrin, dieldrin, chlordane, and others) in concentrations that exceeded the MPC by 10-100 times (Table 3.2). Results showed that amendments changed $M$. sinensis physiological parameters. Specifically, Tween 20 increased the plant height by $16.6 \%$, while AC increased it only by $3.6 \%$, yet it was statistically significant. The opposite tendency was detected in the case of root dry mass. The addition of Tween 20 and AC decreased the mass by $64 \%$ and $49.7 \%$, respectively, while the aboveground biomass increased by $6.6 \%$ in the presence of $\mathrm{AC}$ and decreased by $5 \%$ in the presence of Tween 20.

Ten out of twenty-four chlorinated pesticides present in the soil were found in Miscanthus biomass; however, only five translocated from roots to aboveground plant parts. When soil was amended with Tween 20, the number of pesticides taken up was six, while when the soil was amended by AC only four pesticides were taken up (Figure 3.1). Tween 20 increased the total uptake of pesticides except for 2,4'-DDD where uptake decreased by $38.7 \%$. AC decreased the total uptake of pesticides by $46.6 \%-92.1 \%$ (Figure 3.1). The pesticides in plant tissues were distributed differently: $\gamma-\mathrm{HCH}$ and dieldrin mainly accumulated in the aboveground biomass while $\alpha-\mathrm{HCH}, \beta-\mathrm{HCH}$, aldrin, 2,4'$\mathrm{DDD}$, and endrin accumulated in the roots. When plants were grown in contaminated soil without amendments, 4, $4^{\prime}$-DDE and 4, $4^{\prime}$-DDD were distributed almost equally in different plant parts, while 4,4'-DDT mainly accumulated in the leaves and stems. When contaminated soil was amended by Tween 20 , the effect changed: 4,4'-DDE was mainly accumulated in aboveground biomass; $4,4^{\prime}$-DDD and 4,4'-DDT in the roots. The presence of AC affected the phytostabilization potential of $M$. sinensis in relation to 4,4'-DDE, 4, $4^{\prime}-\mathrm{DDD}, 4,4^{\prime}-\mathrm{DDT}$, i.e., they were mainly accumulated in the root system (Mamirova et al., 2020).

Calculation of the uptake index for ten chlorinated pesticides showed that in soil contaminated by pesticides without or with amendments, $M$. sinensis accumulated 4,4'-DDE more than 4,4'-DDT, followed by 4,4'-DDD which can be explained by high concentration of 4,4'-DDE in the studied soils and its bioavailability due to lower hydrophobicity level. 


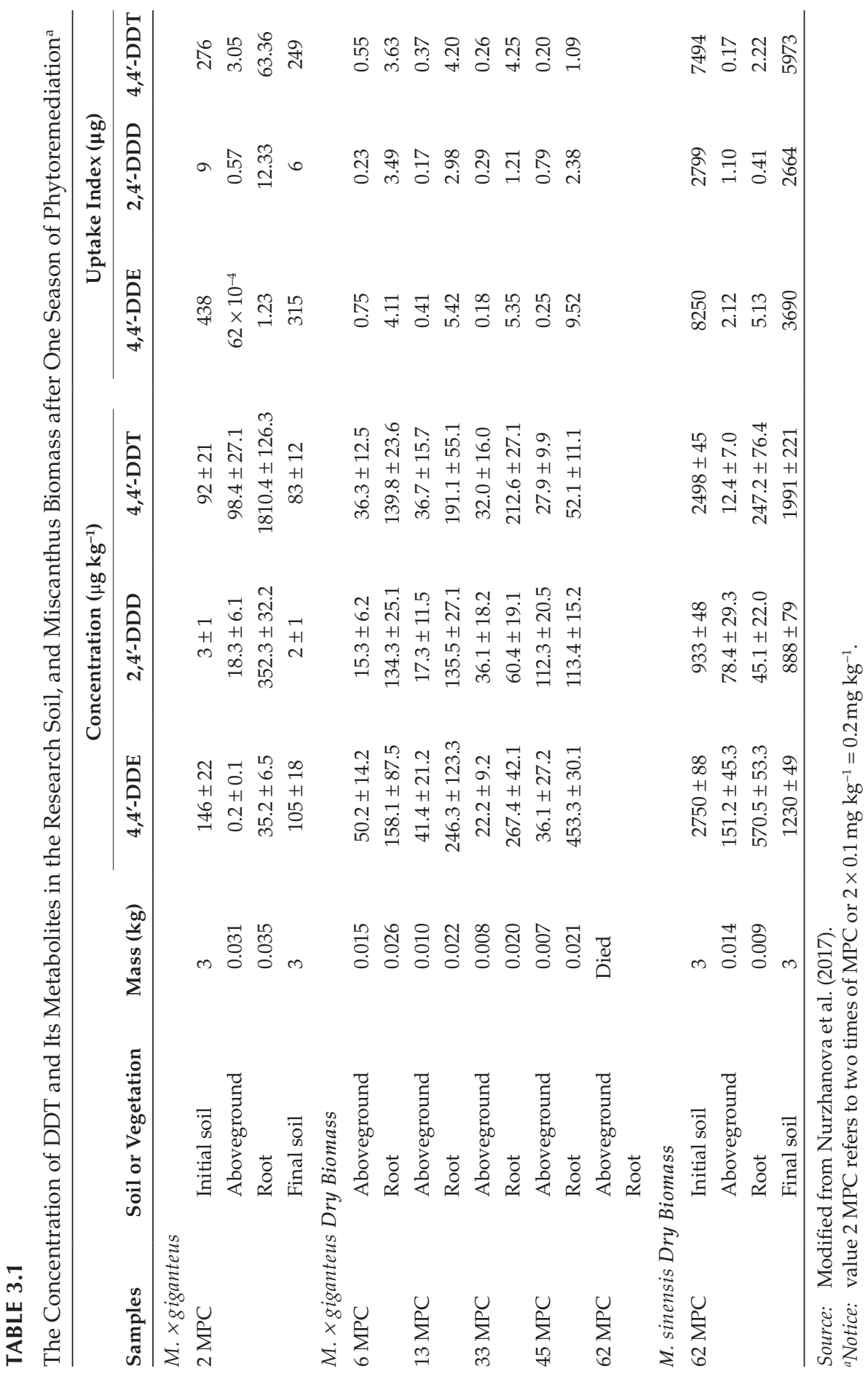




\section{TABLE 3.2}

Concentrations of Chlorinated Pesticides in the Aged Soil

\begin{tabular}{|c|c|c|c|}
\hline Chlorinated Pesticides & MPC KZ, ${ }^{a}\left(\mu \mathrm{gg}^{-1}\right)$ & MPC EU, ${ }^{b}\left(\mu g\right.$ kg $\left.^{-1}\right)$ & Concentration $\left(\mu \mathrm{g} \mathrm{kg}^{-1}\right)$ \\
\hline $2,4^{\prime}-\mathrm{DDD}$ & 100 & 10.0 & $14,072.0 \pm 5,239.0$ \\
\hline $4,4^{\prime}-\mathrm{DDD}$ & 100 & 10.0 & $11,434.0 \pm 7,302.0$ \\
\hline $4,4^{\prime}-\mathrm{DDE}$ & 100 & 10.0 & $777.9 \pm 292.0$ \\
\hline $4,4^{\prime}-\mathrm{DDT}$ & 100 & 10.0 & $10,023.0 \pm 2,471$ \\
\hline Aldrin & 2.5 & 7.0 & $230.2 \pm 59.1$ \\
\hline Chlordane & 100 & 4.3 & $48.1 \pm 27.6$ \\
\hline Chlorobenzilate & 20 & - & $32,061.0 \pm 12,669.0$ \\
\hline Dibutyl chlorendate & - & - & $2134.6 \pm 477.6$ \\
\hline Dieldrin & 0.5 & 7.0 & $132.9 \pm 51.1$ \\
\hline Endosulfan $\alpha$ & 100 & 0.003 & $5.5 \pm 0.0$ \\
\hline Endosulfan $\beta$ & 100 & 0.003 & $253.1 \pm 163.1$ \\
\hline Endosulfan sulfate & - & - & $118.7 \pm 76.5$ \\
\hline Endrin & 1 & 2.9 & $44,085.0 \pm 17,335.0$ \\
\hline Endrin aldehyde & - & 2.9 & $1087.0 \pm 198.0$ \\
\hline $\mathrm{HCB}$ & 500 & 50.0 & $4.7 \pm 1.9$ \\
\hline Heptachlor & 50 & 0.7 & $214.7 \pm 0.0$ \\
\hline Heptachlorepoxide & 50 & 0.052 & $3029.0 \pm 1192.0$ \\
\hline Hexabromobenzene & 30 & 28.0 & $201.4 \pm 129.9$ \\
\hline Keltan (Dicofol) & 100 & - & $34.4 \pm 0.0$ \\
\hline Methoxychlor & 1600 & 900.0 & $435.6 \pm 281.1$ \\
\hline$\alpha-\mathrm{HCH}$ & 100 & 220.0 & $89.2 \pm 0.0$ \\
\hline$\beta-\mathrm{HCH}$ & 100 & 92.0 & $25.5 \pm 16.4$ \\
\hline$\gamma-\mathrm{HCH}$ & 100 & 0.01 & $488.0 \pm 152.0$ \\
\hline$\delta-\mathrm{HCH}$ & 100 & - & $67.4 \pm 13.7$ \\
\hline
\end{tabular}

Source: Modified from Mamirova et al. (2020).

a Maximum Permissible Concentration (MPC) values for the Republic of Kazakhstan (MHRK \& MEPRK, 2004).

b MPC values as for EU (Crommentuijn et al., 2000; Van de Plassche, 1994).

In conclusion, Miscanthus is likely to tolerate at least moderate levels of organic contaminants, unless they are specific plant growth regulators, or membrane disruptors. Whether it is able to metabolize particular organic compounds can only be determined confidently with plants of that genus. There are suggestions that different species or biovars and cultivars (CVs) may vary in capacity within a genus, in general, but there is little clear evidence with Miscanthus. The work of Mamirova et al. (2020) indicates there may be differences for some DDT metabolites. There will no doubt be other examples. 


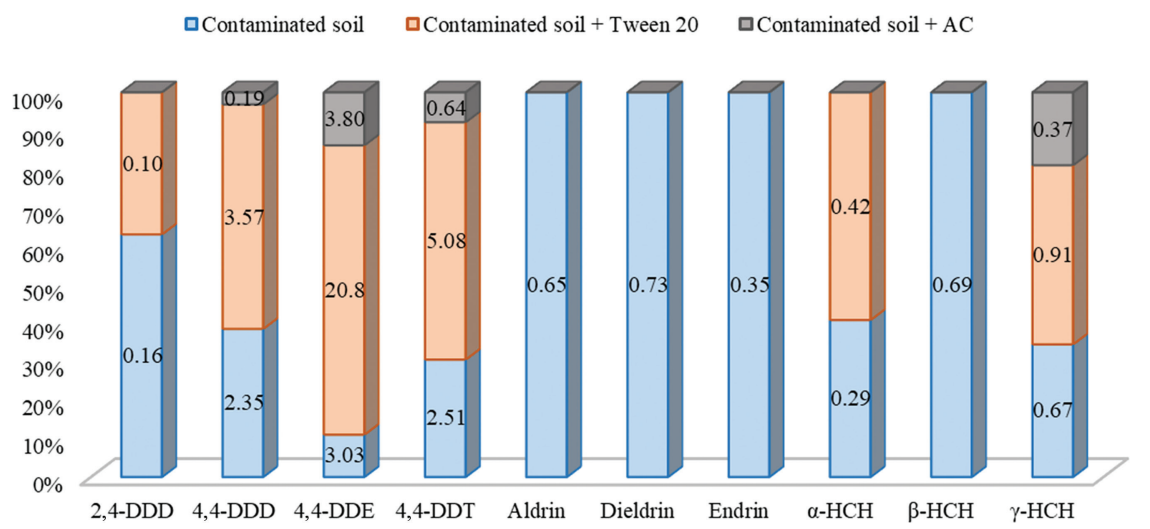

FIGURE 3.1

Total content of chlorinated pesticides in M. sinensis, units - $\mu$ g (Modified from Mamirova et al. (2020).

\section{References}

Abdullah, S. R. S., Al-Baldawi, I. A., Almansoory, A. F., Purwanti, I. F., Al-Sbani, N. H., \& Sharuddin, S. S. N. (2020). Plant-assisted remediation of hydrocarbons in water and soil: Application, mechanisms, challenges and opportunities. Chemosphere, 247, 125932. https://doi.org/10.1016/j.chemosphere.2020.125932.

Afzal, M., Khan, Q. M., \& Sessitsch, A. (2014). Endophytic bacteria: Prospects and applications for the phytoremediation of organic pollutants. Chemosphere, 117(1), 232-242. https://doi.org/10.1016/j.chemosphere.2014.06.078.

Agbeve, S. K., Carboo, D., Duker-Eshun, G., Afful, S., \& Ofosu, P. (2013). Burden of organochlorine pesticide residues in the root of Cryptolepis sanguinolenta, antimalarial plant used in traditional medicine in Ghana. European Chemical Bulletin, 2(11), 936-941. https://doi.org/10.17628/ECB.2013.2.936-941.

Agnello, A. C., Huguenot, D., Van Hullebusch, E. D., \& Esposito, G. (2014). Enhanced phytoremediation: A review of low molecular weight organic acids and surfactants used as amendments. Critical Reviews in Environmental Science and Technology, 44(22), 2531-2576. https://doi.org/10.1080/10643389.2013 .829764 .

An, C. J., Huang, G. H., Wei, J., \& Yu, H. (2011). Effect of short-chain organic acids on the enhanced desorption of phenanthrene by rhamnolipid biosurfactant in soilwater environment. Water Research, 45(17), 5501-5510. https://doi.org/10.1016/j. watres.2011.08.011.

Ancona, V., Barra Caracciolo, A., Grenni, P., Di Lenola, M., Campanale, C., Calabrese, A., Uricchio, V. F., Mascolo, G., \& Massacci, A. (2017). Plant-assisted bioremediation of a historically PCB and heavy metal-contaminated area in Southern Italy. New Biotechnology, 38, 65-73. https://doi.org/10.1016/j.nbt.2016.09.006.

Anderson, E. K. (2011). Herbicide toxicity response and eradication studies in Miscanthus $\times$ giganteus, Thesis (M.S.) in Crop Science, University of Illinois. http://hdl.handle.net/2142/18498. 
Arslan, M., Imran, A., Khan, Q. M., \& Afzal, M. (2017). Plant-bacteria partnerships for the remediation of persistent organic pollutants. Environmental Science and Pollution Research, 24(5), 4322-4336. https://doi.org/10.1007/ s11356-015-4935-3.

Asquer, C., Melis, E., Scano, E. A., \& Carboni, G. (2019). Opportunities for green energy through emerging crops: Biogas valorization of Cannabis sativa L. residues. Climate, 7(12), 142. https://doi.org/10.3390/cli7120142.

Becerra-Castro, C., Prieto-Fernández, Á., Kidd, P. S., Weyens, N., Rodríguez-Garrido, B., Touceda-González, M., Acea, M. J., \& Vangronsveld, J. (2013). Improving performance of Cytisus striatus on substrates contaminated with hexachlorocyclohexane $(\mathrm{HCH})$ isomers using bacterial inoculants: Developing a phytoremediation strategy. Plant and Soil, 362(1-2), 247-260. https://doi.org/10.1007/ s11104-012-1276-6.

Beesley, L., Moreno-Jiménez, E., Gomez-Eyles, J. L., Harris, E., Robinson, B., \& Sizmur, T. (2011). A review of biochars' potential role in the remediation, revegetation and restoration of contaminated soils. Environmental Pollution, 159(12), 32693282. https://doi.org/10.1016/j.envpol.2011.07.023.

Bilalis, D., Karidogianni, S., Roussis, I., Kouneli, V., Kakabouki, I., \& Folina, A. (2019). Cannabis sativa L.: A new promising crop for medical and industrial use. Bulletin of University of Agricultural Sciences and Veterinary Medicine Cluj-Napoca. Horticulture, 76(2), 145. https://doi.org/10.15835/buasvmcn-hort:2019.0020.

Cachada, A., Ferreira da Silva, E., Duarte, A. C., \& Pereira, R. (2016). Risk assessment of urban soils contamination: The particular case of polycyclic aromatic hydrocarbons. Science of the Total Environment, 551-552, 271-284. https://doi. org/10.1016/j.scitotenv.2016.02.012.

Campanella, B. E., Bock, C., \& Schröder, P. (2002). Phytoremediation to increase the degradation of PCBs and PCDD/Fs: Potential and limitations. Environmental Science and Pollution Research, 9(1), 73-85. https://doi.org/10.1007/bf02987318.

Campbell, S., Paquin, D., Awaya, J. D., \& Li, Q. X. (2002). Remediation of benzo[a] pyrene and chrysene-contaminated soil with industrial hemp (Cannabis sativa). International Journal of Phytoremediation, 4(2), 157-168. https://doi. org/10.1080/15226510208500080.

Canadian Council Ministers Environments. (2008). Canada-wide standards for petroleum hydrocarbons (PHC) in soil. https://www.ccme.ca/en/resources/ contaminated_site_management/phc_cws_in_soil.html

Chan-Quijano,J.G., Cach-Perez, M.J., \& Rodriguez-Robles, U. (2020). Phytoremediation of soils contaminated by hydrocarbon. In: Shmaefsky, B. R. ed. Phytoremediation, Concepts and Strategies in Plant Sciences, Springer, New York, 83-101.

Chekol, T., Vough, L. R., \& Chaney, R. L. (2004). Phytoremediation of polychlorinated biphenyl-contaminated soils: The rhizosphere effect. Environment International, 30(6), 799-804. https://doi.org/10.1016/j.envint.2004.01.008.

Chlebek, D., \& Hupert-Kocurek, K. (2019). Endophytic bacteria in the phytodegradation of persistent organic pollutants. Advancements of Microbiology, 58(1), 70-79. https://doi.org/10.21307/PM-2019.58.1.070

Crommentuijn, T., Sijm, D., De Bruijn, J., Van Leeuwen, K., \& Van de Plassche, E. (2000). Maximum permissible and negligible concentrations for some organic substances and pesticides. Journal of Environmental Management, 58(4), 297-312. https://doi.org/10.1006/jema.2000.0334. 
Das, P. (2014). Chemically catalyzed phytoremediation of 2,4,6-trinitrotoluene (TNT) contaminated soil by vetiver grass (Chrysopogon zizanioides L.). Theses, Dissertations and Culminating Projects. Montclair State University. https://digitalcommons.montclair.edu/etd/57.

Dathan, J. (2020). The broken land: The environmental consequences of explosive weapon use. Action on Armed Violence, London, UK. www.aoav.org.uk.

Denyes, M. J., Langlois, V. S., Rutter, A., \& Zeeb, B. A. (2012). The use of biochar to reduce soil PCB bioavailability to Cucurbita pepo and Eisenia fetida. Science of the Total Environment, 437, 76-82. https://doi.org/10.1016/j.scitotenv.2012.07.081.

Denyes, M. J., Parisien, M. A., Rutter, A., \& Zeeb, B. A. (2014). Physical, chemical and biological characterization of six biochars produced for the remediation of contaminated sites. Journal of Visualized Experiments : JoVE, 93, e52183. https://doi. org/10.3791/52183.

Denyes, M. J., Rutter, A., \& Zeeb, B. A. (2013). In situ application of activated carbon and biochar to PCB-contaminated soil and the effects of mixing regime. Environmental Pollution, 182, 201-208. https://doi.org/10.1016/j.envpol.2013.07.016.

Denyes, M. J., Rutter, A., \& Zeeb, B. A. (2016). Bioavailability assessments following biochar and activated carbon amendment in DDTcontaminated soil. Chemosphere, 144, 1428-1434. https://doi.org/10.1016/j. chemosphere.2015.10.029.

Esteve-Núñez, A., Caballero, A., \& Ramos, J. L. (2001). Biological degradation of 2,4,6-trinitrotoluene. Microbiology and Molecular Biology Reviews, 65(3), 335-352. https://doi.org/10.1128/mmbr.65.3.335-352.2001.

Fairchild, J. F., Ruessler, D. S., \& Carlson, A. R. (1998). Comparative sensitivity of five species of macrophytes and six species of algae to atrazine, metribuzin, alachlor, and metolachlor. Environmental Toxicology and Chemistry, 17(9), 1830-1834. https://doi.org/10.1002/etc.5620170924.

Ficko, S. A., Rutter, A., \& Zeeb, B. A. (2011). Phytoextraction and uptake patterns of weathered polychlorinated biphenyl-contaminated soils using three perennial weed species. Journal of Environmental Quality, 40(6), 1870-1877. https://doi. org/10.2134/jeq2011.0144.

Field, J. A., \& Sierra-Alvarez, R. (2008). Microbial degradation of chlorinated dioxins. Chemosphere, 71(6), 1005-1018. https://doi.org/10.1016/j. chemosphere.2007.10.039.

Fiorenza, S., Oubre, C. L., \& Ward, C. H. (2000). Phytoremediation of Hydrocarbon Contaminated Soil, Lewis Publishers, New York.

Gąbka, D., \& Wolski, K. (2011). Use of turfgrasses in landfill leachate treatment. Polish Journal of Environmental Studies, 20(5), 1161.

Gandia-Herrero, F., Lorenz, A., Larson, T., Graham, I. A., Bowles, D. J., Rylott, E. L., \& Bruce, N. C. (2008). Detoxification of the explosive 2,4,6-trinitrotoluene in Arabidopsis: Discovery of bifunctional O- and C-glucosyltransferases. Plant Journal, 56(6), 963-974. https://doi.org/10.1111/j.1365-313X.2008.03653.x.

Glick, B. R. (2010). Using soil bacteria to facilitate phytoremediation. Biotechnology Advances, 28(3), 367-374. https://doi.org/10.1016/j.biotechadv.2010.02.001.

Gonzalez, M., Miglioranza, K. S. B., Aizpún, J. E., Isla, F. I., \& Peña, A. (2010). Assessing pesticide leaching and desorption in soils with different agricultural activities from Argentina (Pampa and Patagonia). Chemosphere, 81(3), 351-358. https://doi. org/10.1016/j.chemosphere.2010.07.021. 
Hemapala, M. U. (2017). Robots for humanitarian demining. In: Canbolat, H. ed. Robots Operating in Hazardous Environments, Books on Demand, Norderstedt, Germany, 3-21. https://doi.org/10.5772/intechopen.70246.

Henner, P., Schiavon, M., Morel, J.-L., Lichtfouse, E., \& Lichtfouse Polycyclic, E. (1997). Polycyclic aromatic hydrocarbon (PAH) occurrence and remediation methods. Analysis, 25(9). https://hal.archives-ouvertes.fr/hal-00193277.

Johnson, R. (2014). Hemp as an agricultural commodity. CRS Report No. RL32725. http://www.pahic.org/white-papers/.

Kalderis, D., Juhasz, A. L., Boopathy, R., \& Comfort, S. (2011). Soils contaminated with explosives: Environmental fate and evaluation of state-of-the-art remediation processes (IUPAC technical eport). Pure and Applied Chemistry, 83(7), 1407-1484. https://doi.org/10.1351/PAC-REP-10-01-05.

Khalid, S., Shahid, M., Murtaza, B., Bibi, I., Natasha, Asif Naeem, M., \& Niazi, N. K. (2020). A critical review of different factors governing the fate of pesticides in soil under biochar application. Science of the Total Environment, 711, 134645. https://doi.org/10.1016/j.scitotenv.2019.134645.

Kumar, S., Singh, R., Kumar, V., Rani, A., \& Jain, R. (2017). Cannabis sativa: A plant suitable for phytoremediation and bioenergy production. In: Bauddh, K., Singh, B., Korstad, J. eds. Phytoremediation Potential of Bioenergy Plants, Springer, Singapore, 269-285. https://doi.org/10.1007/978-981-10-3084-0_10.

Liber, Y., Létondor, C., Pascal-Lorber, S., \& Laurent, F. (2018). Growth parameters influencing uptake of chlordecone by Miscanthus species. Science of the Total Environment, 624, 831-837. https://doi.org/10.1016/j.scitotenv.2017.12.071.

Liu, J., \& Schnoor, J. L. (2008). Uptake and translocation of lesser-chlorinated polychlorinated biphenyls (PCBs) in whole hybrid poplar plants after hydroponic exposure. Chemosphere, 73(10), 1608-1616. https://doi.org/10.1016/j.chemosphere.2008.08.009.

Loffredo, E., Picca, G., \& Parlavecchia, M. (2020). Single and combined use of Cannabis sativa L. and carbon-rich materials for the removal of pesticides and endocrinedisrupting chemicals from water and soil. Environmental Science and Pollution Research, 1-16. https://doi.org/10.1007/s11356-020-10690-7.

Lunney, A. I., Zeeb, B. A., \& Reimer, K. J. (2004). Uptake of weathered DDT in vascular plants: Potential for phytoremediation. Environmental Science and Technology, 38(22), 6147-6154. https://doi.org/10.1021/es030705b.

Mamirova, A., Pidlisnyuk, V., Amirbekov, A., Sevcu, A., \& Nurzhanova, A. (2020). Phytoremediation potential of Miscanthus sinensis And. in organochlorine pesticides contaminated soil amended by Tween 20 and Activated carbon. Environmental Science and Pollution Research. https://doi.org/10.1007/s11356-020-11609-y.

McCutcheon, S. C., \& Schnoor, J. L. (2003). Phytoremediation: Transformation and Control of Contaminants, Wiley, Hoboken, NJ.

Mench, M., Lepp, N., Bert, V., Schwitzguébel, J.-P., Gawronski, S. W., Schröder, P., \& Vangronsveld, J. (2010). Successes and limitations of phytotechnologies at field scale: Outcomes, assessment and outlook from COST Action 859. Journal of Soils and Sediments, 10(6), 1039-1070. https://doi.org/10.1007/s11368-010-0190-x.

MHRK and MEPRK. (2004). Standards for maximum permissible concentrations of harmful substances, pests and other biological substances polluting the $\approx$ soil, approved by a joint order of the Ministry of Health of the Republic of Kazakhstan dated January 30, 2004 No. 99 and the Ministry of Environmental Protection of the Republic of Kazakhstan dated January 27, 2004, No. 21-P. 
Narayanan, M., Davis, L. C., \& Erickson, L. E. (1995). Fate of volatile chlorinated organic compounds in a laboratory chamber with alfalfa plants. Environmental Science and Technology, 29(9), 2437-2444. https://doi.org/10.1021/ es00009a041.

Narayanan, M., Erickson, L. E., \& Davis, L. C. (1999). Simple plant-based design strategies for volatile organic pollutants. Environmental Progress, 18(4), 231-242. https://doi.org/10.1002/ep.670180409.

Nartey, O. D., \& Zhao, B. (2014). Biochar preparation, characterization, and adsorptive capacity and its effect on bioavailability of contaminants: An overview. Advances in Materials Science and Engineering, 2014, 715398. https://doi. org/10.1155/2014/715398.

Nichols, E. G., Cook, R. L., Landmeyer, J. E., Atkinson, B., Malone, D. R., Shaw, G., \& Woods, L. (2014). Phytoremediation of a petroleum-hydrocarbon contaminated shallow aquifer in Elizabeth City, North Carolina, USA. Remediation Journal, 24(2), 29-46. https://doi.org/10.1002/rem.21382.

Nsanganwimana, F., Pourrut, B., Mench, M., \& Douay, F. (2014). Suitability of Miscanthus species for managing inorganic and organic contaminated land and restoring ecosystem services. A review. Journal of Environmental Management, 143, 123-134. https://doi.org/10.1016/j.jenvman.2014.04.027.

Nurzhanova, A., Pidlisnyuk, V., Sailaukhanuly, Y., Kenessov, B., Trogl, J., Aligulova, R., Kalugin, S., Nurmagambetova, A., Abit, K., \& Stefanovska, T. (2017). Phytoremediation of military soil contaminated by metals and organochlorine pesticides using miscanthus. Communication in Agricultural and Applied Biological Sciences, 82, 61-68.

Otani, T., Seike, N., \& Sakata, Y. (2007). Differential uptake of dieldrin and endrin from soil by several plant families and Cucurbita genera. Soil Science and Plant Nutrition, 53(1), 86-94. https://doi.org/10.1111/j.1747-0765.2007.00102.x.

Paul, S., Rutter, A., \& Zeeb, B. A. (2015). Phytoextraction of DDT-contaminated soil at Point Pelee National Park, Leamington, ON, using Cucurbita pepo cultivar Howden and native grass species. Journal of Environmental Quality, 44(4), 12011209. https://doi.org/10.2134/jeq2014.11.0465.

Pidlisnyuk, V., Stefanovska, T., Lewis, E. E., Erickson, L. E., \& Davis, L. C. (2014). Miscanthus as a productive biofuel crop for phytoremediation. Critical Reviews in Plant Sciences, 33(1), 1-19. https://doi.org/10.1080/07352689.2014.847616.

Pillai, H. P. S., \& Kottekottil, J. (2016). Nano-phytotechnological remediation of endosulfan using zero valent iron nanoparticles. Journal of Environmental Protection, 7(5), 734-744. https://doi.org/10.4236/jep.2016.75066.

Plhalova, L., Stepanova, S., Praskova, E., Chromcova, L., Zelnickova, L., Divisova, L., Skoric, M., Pistekova, V., Bedanova, I., \& Svobodova, Z. (2012). The effects of subchronic exposure to metribuzin on Danio rerio. The Scientific World Journal, 2012, 728189. https://doi.org/10.1100/2012/728189.

Ramamurthy, A. S., \& Memarian, R. (2012). Phytoremediation of mixed soil contaminants. Water, Air, and Soil Pollution, 223(2), 511-518. https://doi.org/10.1007/ s11270-011-0878-6.

Rani, M., Shanker, U., \& Jassal, V. (2017). Recent strategies for removal and degradation of persistent \& toxic organochlorine pesticides using nanoparticles: A review. Journal of Environmental Management, 190, 208-222. https://doi.org/10.1016/j. jenvman.2016.12.068. 
Ren, X., Zeng, G., Tang, L., Wang, J., Wan, J., Liu, Y., Yu, Y., Yi, H., Ye, S., \& Deng, R. (2017) Sorption, transport and biodegradation - An insight into bioavailability of persistent organic pollutants in soil. Science of the Total Environment, 610-611, 1154-1163. https://doi.org/10.1016/j.scitotenv.2017.08.089.

Robledo, L., Carrasco, M., \& Mery, D. (2009). A survey of land mine detection technology. International Journal of Remote Sensing, 30(9), 2399-2410. https://doi. org/10.1080/01431160802549435.

Saibu, S., Adebusoye. S. A., \& Oyetibo, G. O. (2020) Aerobic bacterial transformation and biodegradation of dioxins: a review. Bioresources and Bioprocessing, 7, 7. https://doi.org/10.1186/s40643-020-0294-0.

Santharam, S., Ibbini, J., Davis, L. C., \& Erickson, L. E. (2011). Field study of biostimulation and bioaugmentation for remediation of tetrachloroethene in groundwater. Remediation Journal, 21(2), 51-68. https://doi.org/10.1002/rem.20281.

Santoyo, G., Moreno-Hagelsieb, G., del Carmen Orozco-Mosqueda, M., \& Glick, B. R. (2016). Plant growth-promoting bacterial endophytes. Microbiological Research, 183, 92-99. https://doi.org/10.1016/j.micres.2015.11.008.

Squillace, P. J., Pankow, J. F., Korte, N. E., \& Zogorski, J. S. (1997). Review of the environmental behavior and fate of methyl tert-butyl ether. Environmental Toxicology and Chemistry, 16(9), 1836-1844. https://doi.org/10.1002/etc.5620160911.

Tang, K. H. D. (2019). Phytoremediation of soil contaminated with petroleum hydrocarbons: A review of recent literature. Global Journal of Civil and Environmental Engineering, 1, 33-42. https://doi.org/10.36811/gjcee.2019.110006.

Tarla, D. N., Erickson, L. E., Hettiarachchi, G. M., Amadi, S. I., Galkaduwa, M., Davis, L. C., Nurzhanova, A., \& Pidlisnyuk, V. (2020). Phytoremediation and bioremediation of pesticide-contaminated soil. Applied Sciences, 10(4), 1217. https://doi. org/10.3390/app10041217.

Técher, D., D’Innocenzo, M., Laval-Gilly, P., Henry, S., Bennasroune, A., MartinezChois, C., \& Falla, J. (2012a). Assessment of Miscanthus x giganteus secondary root metabolites for the biostimulation of PAH-utilizing soil bacteria. Applied Soil Ecology, 62, 142-146. https://doi.org/10.1016/j.apsoil.2012.06.009.

Técher, D., Laval-Gilly, P., Henry, S., Bennasroune, A., Formanek, P., MartinezChois, C., D’Innocenzo, M., Muanda, F., Dicko, A., Rejšek, K., \& Falla, J. (2011). Contribution of Miscanthus x giganteus root exudates to the biostimulation of PAH degradation: An in vitro study. Science of the Total Environment, 409(20), 4489-4495. https://doi.org/10.1016/j.scitotenv.2011.06.049.

Técher, D., Martinez-Chois, C., Laval-Gilly, P., Henry, S., Bennasroune, A., D'Innocenzo, M., \& Falla, J. (2012b). Assessment of Miscanthus x giganteus for rhizoremediation of long term PAH contaminated soils. Applied Soil Ecology, 62, 42-49. https://doi.org/10.1016/j.apsoil.2012.07.009.

Terzaghi, E., Alberti, E., Raspa, G., Zanardini, E., Morosini, C., Anelli, S., Armiraglio, S., \& Di Guardo, A. (2021). A new dataset of PCB half-lives in soil: Effect of plant species and organic carbon addition on biodegradation rates in a weathered contaminated soil. Science of the Total Environment, 750, 141411. https://doi. org/10.1016/j.scitotenv.2020.141411.

USEPA. (2015). Revegetating landfills and waste containment areas fact sheet. https:// www.epa.gov/sites/production/files/2015-08/documents/revegetating_fact_ sheet.pdf.

USEPA. (n.d.). Polychlorinated biphenyls (PCBs). https://www.epa.gov/pcbs/ learn-about-polychlorinated-biphenyls-pcbs. 
Van de Plassche, E. J. (1994). Towards integrated environmental quality objectives for several compounds with a potential for secondary poisoning. RIVM Rapport 679101012.

Vetiver Network International. (2017). Vetiver system for landfill leachate treatment. http://www.vetiver.org/TVN_VS_GAL_PUB/VS_Landfill_leachate_o.pdf.

Via, S. M. (2020). Phytoremediation of explosives. In: Shmaefsky, B. R. ed. Phytoremediation: Concepts and Strategies in Plant Sciences, Springer, New York, 261-284.

Wechtler, L., Henry, S., Falla, J., Walderdorff, L., Bonnefoy, A., \& Laval-Gilly, P. (2020). Polycyclic aromatic hydrocarbons (PAHs) dissipation from a contaminated technosol composed of dredged sediments with Miscanthus $\times$ giganteus and Trifolium repens L. in mono- and co-culture. Journal of Soils and Sediments, 20, 2893-2902. https://doi.org/https://doi.org/10.1007/s11368-020-02648-6.

White, J. C., \& Kottler, B. D. (2002). Citrate-mediated increase in the uptake of weathered 2,2-bis( $p$-chlorophenyl)1,1-dichloroethylene residues by plants. Environmental Toxicology and Chemistry, 21(3), 550-556. https://doi.org/10.1002/ etc.5620210312.

Wilke, B.-M., \& Metz, R. (1993). Soil/Plant Transfer of Pollutants by Cultivation of Energy Plants on Waste Water Irrigated Soils. In: Arendt, F. et al., eds. Contaminated Soil '93, Kluwer Publishing Co, Dordrecht, Netherlands, 581-582. https://doi.org/10.1007/978-94-011-2018-0_112. 